\title{
The Responsibilities of Accountants
}

\author{
Ronald F. Duska \\ Charles Lamont Post Chair of Ethics and the Professions, The American College, 270 South Bryn Mawr \\ Ave., Bryn Mawr, PA 19010, U.S.A. \\ E-mail: Ronald.Duska@TheAmericanCollege.edu
}

An accountant is a good accountant if in practicing his craft he is superb in handling the numbers. But a good accountant in handling the numbers can use that skill to misstate earnings to cover a multitude of problems with a company's books while staying within the law. So, the notion of a moral or ethical accountant is not the same as the notion of a good accountant. Our general principle would be that to be ethical a person has a responsibility to fulfil one's role or roles, as long as that role or roles are in conformity with acceptable goals for human life. What we mean by acceptable goals for human life are those that lead to societies where there are goods fairly distributed, which contribute to the quality of life in a way that allows as many people as possible to live fulfilled, abundant and flourishing lives. Assuming that our economic system and the businesses within it lead to a society such as that described above, the accountant has a role to play in that system which will specify the accountant's responsibilities. If accounting is the language of business, it is the auditor's job to see the language is used properly so that relevant material is communicated properly. In the system, the role of the independent auditor is to be a watchdog, "to see whether the company's estimates are based on formulas that seem reasonable in the light of whatever evidence is available and that choice formulas are applied consistently from year to year." 1 The responsibility of the auditors derived from their function is clear. The ultimate responsibility of internal auditors is to develop statements that present the financial situation of the company in a fair way, meaning as much disclosure as necessary to give a reasonable picture of the financial situation to any user having a claim to that knowledge. The function of the external auditor is to affirm that has happened by issuing an opinion as to whether the financial statement fairly presents the financial position of the corporation. The fulfillment of those functions is what is required for an efficient financial market. Those functions set the standards, the spirit of which has been seriously violated in recent years. Too much attention to the question of whether the financial statements formally complied with principles, practices and conventions accepted at the time should not be permitted to blind us to the basic question of whether the financial statements performed the function of enlightenment, which is their primary reason for existence. ${ }^{2}$ By virtue of their attest function, accountants/auditors belong to the class of gatekeeper intermediaries in the financial markets who have a "watchdog" responsibility. That responsibility requires the virtue of professional skepticism. "Due professional care requires the auditor to exercise professional skepticism." "An audit of financial statements in accordance with generally accepted auditing standards should be planned and performed with an attitude of professional skepticism." We lay out the practical requirements of meeting the obligations of skepticism, as well as looking at difficulties in maintaining such an attitude toward long time clients. The paper concludes by examining the following question. What caused this lack of due care? Why did the accounting firms fall short?

\footnotetext{
${ }^{1}$ Encyclopedia Britannica, Vol. "Accounting”.

${ }^{2}$ Quoted in Briloff (1999, p. 5).
} 
Is this skepticism a realistic expectation? How much more do the other gatekeeper intermediaries contribute to the malaise?

The Geneva Papers (2005) 30, 410-424. doi:10.1057/palgrave.gpp.2510042

Keywords: accounting; responsibility; business; skepticism; auditing; financial markets

In the domain of art voluntary error is not so bad as involuntary, but it is worse in the case of prudence as it is in the case of all the virtues or excellences.

Aristotle, Ethics, Book 6, Chapter 5, 1140b22 I

\section{Introduction}

It has often been pointed out that the practice of accounting is an art, not a science. That is most likely true. Any application of principles to reality is an art. Just as in medicine the doctor takes his knowledge and applies it to the patient, so in accounting the accountant takes his expertise and applies it to financial matters to develop or evaluate financial statements. But being a superb artist does not mean being an ethical one as is clear in the case of the clever thief. We can admire the skill and acumen of the thief while recognizing that what the thief does is unethical. We can admire the financial acumen of an Andy Fastow without approving of what he did.

Aristotle in his remarkable book The Nicomachean Ethics points out the difference between art and ethics by contrasting voluntary error with involuntary error. In art, no matter what you are doing with your art, you can do it well or poorly. In this case the question is whether you do what you do aptly or poorly. In ethics we judge whether what you do is ethical or not. In ethics, we judge the ultimate purpose of the art.

Thomas Aquinas, the superb medieval commentator on Aristotle, puts the matter this way:

Reason stands in different relations to the productions of art and to moral acts. In matters of art, reason is directed to a particular end, which is something devised by reason; whereas in moral matters, it is directed to the universal end of all human life.

Since moral failure is a departure from that universal end and artistic failure is a departure from the particular end, failure "can occur in two ways in the operation of art. First by a departure from the particular end intended by the artist, a failure proper to the art: e.g., if an artist produces a bad thing, while intending to produce something good, or produce something good, while intending to produce something bad. Secondly, by a departure from the universal end of human life. But this failure is not proper to the artist as an artist, but as a man. Consequently, for the former failure, the artist is blamed as an artist, while for the latter he is blamed as a man". 
In moral matters, where we take into consideration the order of reason to the universal end of human life, moral failures are always due to a departure from the order of reason to the universal end of human life. ${ }^{3}$

What this means is that an accountant is a good accountant if in practicing his craft he is superb in handling the numbers. But a good accountant in handling the numbers can use that skill to misstate earnings to cover a multitude of problems with a company's books while staying within the law. So, the notion of a moral or ethical accountant is not the same as the notion of a good accountant. To be a moral or ethical accountant one must do more than just cleverly apply accounting or auditing principles, one must do that for a worthwhile or noble goal. These considerations give us a framework from within which we can evaluate the ethical responsibilities of the accountant. Indeed when we look at the two sets of principles that accountants adhere to, Accounting Principles (be they GAAP or others) and Codes of Ethics, they seem to reflect this duality. If you are clever, you can game the GAAP and violate your ethical responsibilities.

In light of this, how does one determine which are the ethical responsibilities? One determines them by deciding what is necessary to bring about one's ultimate ethical goals, and how one's profession or role fits into those goals. Our general principle would be that to be ethical a person has a responsibility to fulfil one's role or roles, as long as that role or roles are in conformity with acceptable goals for human life. What we mean by acceptable goals for human life are goods fairly distributed which contribute to the quality of life in a way that allows as many people as possible to live fulfilled, abundant and flourishing lives.

If our economic system has those acceptable goals as its proper end and contributes to the achievement of such goals (see Adam Smith and arguments for the beneficence of free market capitalism), and the system has prescribed roles with tasks necessary to be met to bring about such a society, then when one assumes such a role one takes on a responsibility to fulfil that role to the best of one's ability.

\section{The responsibilities of the accounting firm}

Let us assume that our economic system brings about acceptable goals. ${ }^{4}$ What exactly are the primary responsibilities of accountants/auditors and auditing firms? What function should they fulfill to help the economic system move forward in a way that will benefit individuals and society? In short, what is the purpose of accountants in the economy?

\footnotetext{
${ }^{3}$ Thomas Aquinas (1947), Summa Theologica, I-II, Q.21 art. 2, ad. 2.

${ }^{4}$ Critics of Capitalism, of course, might challenge that assumption. But that is a subject for another paper. Further, one could argue that capitalism is the most successful economic system in the history of the world in terms of bringing about the greatest number of material goods, but claim that the distribution of those goods is unfair. This is the larger question of economic justice. But assuming one could solve the distribution problem, the role of the accountant is still a required role, and little would change with respect to the accountants' major responsibilities.
} 
Given the way financial markets and the economic system have developed, society has carved out a vital role for the accountant and independent auditor, which is absolutely essential for the effective functioning of the economic system. While we will concentrate most on the role of the external auditor, much of what we say can and should apply to internal auditors and management accountants. If accounting is the language of business, it is the auditor's job to see that the language is used properly so that relevant material is communicated properly. In the system, the role of the independent auditor is to be a watchdog, "to see whether the company's estimates are based on formulas that seem reasonable in the light of whatever evidence is available and that choice formulas are applied consistently from year to year." All of this of course is necessary to bring about efficient markets, which are necessary for the system to bestow its benefits most productively.

John Bogle the founder of The Vanguard Group puts these points succinctly:

The integrity of financial markets - markets that are active, liquid, and honest, with participants who are fully and fairly informed-is absolutely central to the sound functioning of any system of democratic capitalism worth its salt... Only the complete confidence of investors in the integrity of the financial information they received allowed these investment needs to be met at the lowest possible cost of capital.

Sound securities markets require sound financial information. It is as simple as that. Investors require - and have a right to require - complete information about each and every security, information that fairly and honestly represents every significant fact and figure that might be needed to evaluate the worth of a corporation. Not only is accuracy required but also, more than that, a broad sweep of information that provides every appropriate figure that a prudent, probing, sophisticated professional investor might require in the effort to decide whether a security should be purchased, held or sold. Those are the watchwords of the financial system that has contributed so much to our (economic) growth, progress, and prosperity.

It is unarguable, I think, that the independent oversight of financial figures is central to that disclosure system. Indeed independence is at integrity's very core. And, for more than a century, the responsibility for the independent oversight of corporate financial statements has fallen to (the) public accounting profession. It is the auditor's stamp on a financial statement that gives it its validity, its respect, and its acceptability by investors. And only if the auditor's work is comprehensive, skeptical, inquisitive and rigorous can we have confidence that financial statements speak the truth. ${ }^{6}$

Bogle's articulation of the necessary function and consequent responsibility of the auditor is not new. It is simply a reiteration of the classic statement of the auditor's

\footnotetext{
5 Encyclopedia Britannica, Vol. "Accounting”.

${ }^{6}$ John C. Bogle, (2000) Public Accounting: Profession or Business? NYU, 10/16/00.
} 
function and responsibility given by Justice Burger's opinion in the 1984 landmark Arthur Young case. ${ }^{7}$ As Burger says:

Corporate financial statements are one of the primary sources of information available to guide the decisions of the investing public. In an effort to control the accuracy of the financial data available to investors in the securities markets, various provisions of the federal securities laws require publicly held companies to file their financial statements with the Securities and Exchange Commission. Commission regulations stipulate that these financial reports must be audited by an independent CPA in accordance with generally accepted auditing standards. By examining the corporation's books and records, the independent auditor determines whether the financial reports of the corporation have been prepared in accordance with generally accepted accounting principles. The auditor then issues an opinion as to whether the financial statements, taken as a whole, fairly present the financial position and operations of the corporation for the relevant period. (Italics mine)

According to Burger, the responsibility of the auditor is clear - to issue an opinion as to whether the financial statement fairly presents the financial position of the corporation.

What does it take to issue an opinion about whether a financial statement fairly presents the financial position of a corporation? Meeting this responsibility requires an auditor to have as much competence, integrity and honesty as possible. To assure that the financial statement is a fair representation of the financial position of the company, it is essential that the integrity and honesty of the auditor not be imperilled by the presence of undue influence and conflicts of interest, which means the auditor must have as much independence as possible. If the market is to function efficiently, those who need to make decisions about the company must be able to trust the accountants' pictures so they can make the decisions based on as accurate and reliable information as possible. Obviously such trust is eroded if there is even an appearance of a conflict of interest, particularly in places like financial markets where perception is often reality.

This role is not without its problems. It creates a special responsibility to the public that is unique to the accountant, and it puts the accountant in a different relation to the client who hires him or her from the relationships with clients other professionals have. Justice Burger mentions this in his statement of auditor responsibility:

The auditor does not have the same relationship to his client than a private attorney who has a role as "... a confidential advisor and advocate, a loyal representative whose duty it is to present the client's case in the most favorable possible light", 8

An independent CPA performs a different role. By certifying the public reports that collectively depict a corporation's financial status, the independent auditor

\footnotetext{
${ }^{7} 464$ U.S. 805, 1984.

${ }^{8}$ As quoted in Briloff (1999).
} 
assumes a public responsibility transcending any employment relationship with the client. (Italics mine.) The independent public accountant performing this special function owes ultimate allegiance to the corporation's creditors and stockholders, as well as to the investing public. This "public watchdog" function demands that the accountant maintain total independence from the client at all times and requires complete fidelity to the public trust.

However, as Barker and Hayes note, "This unusual arrangement poses an ethical dilemma for public accountants." 9 They point out that clients usually expect their accountants to perform their professional services in a manner that benefits the client. As we have seen, such an expectation is misguided since, as Burger said, the accountant's responsibilities are to the legitimate users of the statements, not necessarily the client. In short, the nature of auditing obliges the accountants to serve "the interests of third parties who are the beneficiaries of the contractual arrangements between the public accountant and their clients".

This obviously creates a difficulty for while the auditors' clients are the ones who pay the fees for the auditor's services, the auditor's primary responsibility is not to look out for the interests of that employer/client, but to look out for the interests of a third party, the public. The auditor is knowledgeable of and monetarily dependent on the client who pays the bill, but primarily responsible to the using public. Such a situation cannot help but create conflicts of interest and ethical conundrums for auditors. In sum, accountants are professionals and consequently should behave as professionals, but while other professionals are obliged to look out for the best interest of their clients, the auditors, while offering services to their clients, must evaluate their client's work and make that evaluation public.

It is extremely difficult performing a "public watchdog function" over a company with which one has such close ties. As we noted, Andersen had a dependency relationship with its clients because of its consulting operations, which brought in more revenue than its auditing operations. Because of the inherent difficulty of this conflict, many have suggested that another kind of compensation system should be worked out where the auditor is not dependent on the client being audited for payment. Others, however, insist that there are precious few cases of auditors not taking their responsibility to the public seriously, so that the current system is sufficient. We leave that question for another study.

There is a second difficulty that needs to be addressed. There has been some question as to whether Burger and others do not go too far in asserting that the auditor's responsibility is to attest to the fairness of the statements. They would claim that the responsibility is merely to attest to the fact that the statements conform to Generally Accepted Accounting Principles (GAAP), arguing that it is difficult if not impossible to determine what counts as fair. ${ }^{10}$ Common sense can provide some

\footnotetext{
${ }^{9}$ Baker and Hayes (1996).

${ }^{10}$ I have covered this issue more extensively in an article forthcoming in The Journal of Business Ethics, "The Good Auditor-Skeptic or Wealth Accumulator? Ethical Lessons Learned From the Arthur Andersen Debacle".
} 
guidance, for there seems to be a sense in which the notion of "fairly" presented means that the report that is being audited will give the reasonable person a fairly good picture of the financial status of the entity being looked at. To rest solely on GAAP is not prudent for there are numerous examples of how GAAP principles can be used by artful dodgers to hide the real health or sickness of a company. Obviously one can use pro forma accounting to be creative in one's accounts. Indeed, one accountant has suggested that accounting is an art, and a truly proficient artist can by the skilful use of GAAP make the same company look to be dizzyingly successful or failing miserably. But such "creative accounting" fails to meet the accountant/auditor's responsibilities.

SEC Commissioner A.A. Sommer Jr. points out that:

Judge Henry J. Friendly, surely one of the most knowledgeable of federal judges in financial and accounting matters, said... in effect (in Continental Vending) ...that the first law for accountants was not compliance with generally accepted accounting principles, but rather full and fair disclosure, fair presentation, and if the principles did not produce this brand of disclosure, accountants could not hide behind the principles but had to go beyond them and make whatever additional disclosures were necessary for full disclosure. ${ }^{11}$

\section{A federal judge in Herzfeld vs. Laventhol sums up our point:}

Compliance with generally accepted accounting principles is not necessarily sufficient for an accountant to discharge his public obligation. Fair presentation is the touchstone for determining the adequacy of disclosure and financial statements. While adherence to generally accepted accounting principles is a tool to help achieve that end, it is not necessarily a guarantee of fairness.

Too much attention to the question of whether the financial statements formally complied with principles, practices and conventions accepted at the time should not be permitted to blind us to the basic question of whether the financial statements performed the function of enlightenment, which is their only reason for existence. ${ }^{12}$

One can assert, without fear of contradiction, that what did in fact happen was that auditors hid behind the GAAP, and not only hid behind conformity with GAAP or Pro Forma principles, but manipulated them to manage books in ways that were beneficial to the clients and harmful to the public who had a right to know the true financial picture of the company. Consequently, auditing firms fell short of fulfilling their ethical responsibilities as auditors.

Returning to our main point, we note that the ultimate responsibility of internal auditors is to certify or attest to the fact that the statements that present the financial situation of the company are presented fairly, meaning that as much disclosure as is necessary is given to offer a reasonable picture of that financial situation to any user

\footnotetext{
${ }^{11}$ Quoted in Briloff (1999, pp. 4-5).

12 Quoted in Briloff (1999, p. 5).
} 
having a claim to that knowledge. That should be the standard practice and it is what is required for an efficient market. Unfortunately, it is also a standard whose spirit has been seriously violated in recent years.

\section{The skeptical watchdog}

Besides their attest function and the responsibility to certify the fairness of financial reports, auditors have another responsibility to the markets. Their attest function makes accountants/auditors part of a class of gatekeeper intermediaries in the financial markets who have a "watchdog" responsibility. There are accountants, investment advisers and rating agencies, all of whom are designated by regulations as necessary bodies charged with keeping the markets transparent and the consumer informed. One could argue that they have all failed miserably in their watchdog function of late. The legal requirement of audited statements, which the government established for the protection of the investing public, gives accountants a monopoly on attesting to the validity of statements. This leads the public to believe that most of the information they receive is useful. To fail in this function is to fail in fulfilling one of accountant's chief responsibilities.

But what sort of responsibilities are they? One of the most important responsibilities was laid out in the American Institute of Certified Public Accountants' (AICPA) Statement of Auditing Standards, No. 53, published in 1988. It was a responsibility to detect error, irregularities or fraud. In 1997 SAS 53, “The Auditor's Responsibility To Detect And Report Errors And Irregularities" was replaced by standard No. 85, "Consideration of Fraud in a Financial Statement Audit", which dropped the words "responsibility" and "irregularities" in favour of "consideration" and "fraud". Whether the change was for the better or was an attempt to evade "responsibility" is not clear, but a look at both documents can give us an indication of what this "watchdog" responsibility of auditors entails, regardless of the title of the standard. ${ }^{13}$

These two documents ${ }^{14}$ lay out specific practices that auditors should follow in setting up audits, and they can be particularly useful in evaluating recent behaviour of accounting firms such as Arthur Andersen. When one looks at recent behaviour, in many cases auditing firms did not take their responsibility to detect error irregularities or fraud seriously. There is documented evidence indicating that Sherron Watkins who blew the whistle on Andersen's handling of Special Purpose Entities (SPE's) found

${ }^{13}$ Cf. the AICPA Statements on Auditing Standards No. 55 SAS53 entitled "The Auditor's Responsibility To Detect And Report Errors And Irregularities."

${ }^{14}$ In the American Institute of Certified Public Accountants' Statements on Auditing Standards (SAS), the section titled: "The Auditor's responsibility to detect errors and irregularities." (SAS 53) has been superseded (whether for better or worse I hesitate to say) by a section called "Consideration of Fraud in a Financial Statement Audit. (SAS 82) (I am somewhat bemused by the fact that the word "responsibility" found in the title of SAS 53 is jettisoned and replaced by the word "consideration" in SAS 82 . Be that as it may SAS 82 still refers to the "responsibility" of auditors in its summary.) So far as I can tell, never in his testimony to congressional committees, did Joseph Berardino (the CEO of Arthur Andersen), refer to the ethical obligation of Andersen to detect irregularities or its responsibility to investigate fraud". 
Enron's accounting procedures suspect. ${ }^{15}$ Subsequent memos coming out of Andersen indicated uneasiness with the procedures, but nothing was done about it. Yet, an examination of the audit standards indicate clearly that Andersen had a responsibility to act on those perceived irregularities of Enron. In the case of another company for whom they were the auditors, Andersen failed to take seriously irregularities that occurred in Global Crossing IRU Swaps, where the swaps had no legitimate business use except to bolster earning statements. Rather, in that case Andersen, acting as consultant, recommended the swap.

If we look a bit more carefully at these under-publicized ethical standards, we see that they not only provide guidance for the responsibility to detect errors, irregularities and fraud ${ }^{16}$ in an audit but also describe factors that influence the auditor's ability to detect those irregularities and explain how exercising due care requires giving appropriate consideration to the possibilities of those errors, irregularities and/or fraud. Finally, the audit standards spell out the auditor's responsibility for communicating those discovered errors, irregularities and/or fraud both within and without the organization whose financial statements are being audited.

According to these standards, an auditor has a responsibility to look for material misstatements or misappropriations of assets or liabilities as well as to assess the risk that errors and irregularities may cause the financial statements to contain a material misstatement. Such a risk assessment requires the auditor to design the audit in such a way as to provide "reasonable assurance" of detecting errors, irregularities or fraudulent claims that are material (one large enough to influence a user of the statement to act in a way he or she would not act if there were no misstatement) to the financial statements.

To assess risk, the auditor needs to understand "a number of factors from management's characteristics and influence over the control environment, industry conditions and operating characteristics and financial stability.",17

An auditor may not be able to detect a material irregularity because generally accepted auditing standards do not require the authentication of documents, or there may be collusion and concealment. For example, because of forgery an auditor may not be able to detect a material irregularity, or if a high-level manager is involved in a cover up it may go undetected because of a lack of a proper internal control structure. Nevertheless, the standards require that "The auditor should exercise (a) due care in planning, performing, and evaluating the results of audit procedures, and (b) the proper degree of professional skepticism to achieve reasonable assurance that material errors or irregularities will be detected." ${ }^{18}$ While the auditor is not an insurer and while his report does not constitute a guarantee of the accuracy of the statements, the

\footnotetext{
${ }^{15}$ Whether they contained irregularities or constituted fraud would make for an interesting discussion but is beyond the scope of this article.

${ }^{16}$ We reiterate. Standard 85, which superceded SAS 53 eliminated the words "responsibility" and "irregularities". We are not clear why the Auditing Standards Board took this approach, but we will view it as a minor technical move. In this book, we will continue to refer to "errors, irregularities and/or fraud".

${ }^{17}$ SAS 82.16 .

${ }^{18}$ SAS 53.08 .
} 
auditor does have a responsibility to adopt the proper degree of professional skepticism:

Due professional care requires the auditor to exercise professional skepticism. An audit of financial statements in accordance with generally accepted auditing standards should be planned and performed with an attitude of professional skepticism. ${ }^{19}$

Let us examine this requirement of skepticism.

The Generally Acceptable Auditing Standards define skepticism as:

... an attitude that includes a questioning mind and a critical assessment of audit evidence. The auditor uses the knowledge, skill, and ability called for by the profession of public accounting to diligently perform, in good faith and with integrity, the gathering and objective evaluation of evidence. ${ }^{20}$

This means that...

The auditor neither assumes that management is dishonest nor assumes unquestioned honesty. Rather, the auditor recognizes that conditions observed and evidential matter obtained, including information from prior audits, need to be objectively evaluated to determine whether the financial statements are free of material misrepresentation. ${ }^{21}$

One can seek in vain for any indication of a skeptical attitude of Andersen the auditor toward Enron the client. If that is the case, Andersen failed in its responsibilities with respect to Enron. Further, in the case of Global Crossing, Andersen was not only not skeptical, it actively encouraged the questionable swaps, which should qualify as an irregularity. Common sense points out what may be a cause of the lack of skepticism. It is difficult to neither assume honesty nor dishonesty when dealing with clients whom one has known for a long time, or on whom one depends for a large part of one's income stream. But the question of whether skepticism is possible in the present system is a separate issue (Nemo dat quod non habet, that is, no one gives what one does not have). The fact is that the standards require such skepticism.

Further, the standards spell out quite specifically what is necessary to be properly skeptical. The skeptical auditor needs to consider factors that influence audit risk especially the internal control structure.

During planning the auditor should assess the risk of material misstatements:

- "The auditor's understanding of the internal control structure should either heighten or mitigate the auditor's concern about the risk of material misstatements."

\footnotetext{
${ }^{19}$ SAS 53.08.

${ }^{20}$ SAS no. 1, section 230.

${ }^{21}$ SAS 53.16.
} 
The auditor should consider the following questions:

- Are there significant difficult-to-audit transactions?

- Are there significant and unusual related party transactions not in the ordinary course of business?

- Are there a significant number of known and likely misstatements detected in the audit of prior period's financials from the predecessor auditor?

The standards further require the auditor to review information about risk factors and the internal control structure by considering matters such as the following:

- Are there circumstances that may indicate a management predisposition to distort financial statements?

- Are there indications that management has failed to establish policies and procedures to assure reliable accounting estimates, by utilizing unqualified, careless or inexperienced personnel?

- Are there indications of lack of control, such as recurrent crisis conditions, disorganized work areas, excessive back orders, shortages, delays or lack of documentation for major transactions?

- Are there indications of a lack of control over computer processing?

- Are there inadequate policies and procedures for security of data or assets? ${ }^{22}$

Finally:

The auditor needs to consider the effects of these matters on the overall audit strategy. High risk ordinarily demands more experienced personnel and more extensive supervision. Higher risk will also ordinarily cause the auditor to exercise a heightened degree of professional skepticism in conducting the audit. ${ }^{23}$

Finally, the standards emphasize that auditors need to be able to cope with illegalities and/or questionable acts within an agreed-upon framework. The accountant may have an obligation to blow the whistle, but that should not be laid upon the accountant without some protections. The auditor "ought to be able to approach the detection and disclosure of illegal or questionable acts by management within a defined and agreed-on framework". ${ }^{24}$ The framework should include a policy on corporate conduct and a system to monitor compliance with the corporate conduct. The auditor should determine whether the operations of the company comply with the standards of corporate conduct. The auditor should also consider illegal or questionable acts without regard for their materiality.

Those then are the responsibilities of the auditor under his obligation to detect irregularities and fraud. ${ }^{25}$ I will not bother to go through an exhaustive litany of the

22 SAS 53.12

${ }^{23}$ See SAS 53.16 to .21, SAS 82.27, and SAS No. 1 AU sec. 230, paragraphs 7-9.

${ }^{24}$ Reahi-Belkhauli (1992, p. 37).

${ }^{25}$ Some might object that with the replacement of the standard that called for the auditor's responsibility to detect errors and irregularities, those tasks fail to be ethical requirements for auditors. The obvious answer is that if such an obligation was necessary for the auditor's to perform their watchdog function, then it is an ethical obligation, and the AICPA's revision of the responsibility does not make existing obligations to go away. 
places where firms such as Andersen fell short in their responsibility to be skeptical of companies such as Enron and Global Crossing. But a brief look at the first three areas of concern ought to indicate Andersen's failure.

- "The auditor's understanding of the internal control structure should either heighten or mitigate the auditor's concern about the risk of material misstatements." In the case of Enron, the internal control structure was such that Andrew Fastow's ownership of SPE's was only allowed by Enron waving its conflict of interest stipulations in its code of ethics. In the case of Global Crossing Andersen set up the internal control structure and recommended the swaps.

- Are there significant difficult-to-audit transactions? In the case of Enron, the SPE's and the Mahonia transactions were virtually impossible to keep track of. Again, in Global Crossing, Andersen as consultant set up the IRU transactions.

- Are there significant and unusual related party transactions not in the ordinary course of business? The relationships between Enron and Special Purpose entities are well known, for example, Chewco, JEDI, LJM1, LJM2. "26 "In GX the transactions had little purpose beyond increasing the company's revenue at the end of each quarter."

In short, Andersen did not live up to its responsibilities as outlined in the auditing standards (GAAS) put forward by the AICPA.

We can then summarize the major responsibilities of the auditor as first being responsible to the using public for evaluating financial statements and declaring that they represent a fair picture of the financial situation of a company, and second of being a watchdog and calling into question irregular practices that would distort those pictures.

\section{Causes of ethical failure}

But what caused this lack of due care? Why did the accounting firms fall short? Is this skepticism a realistic expectation? How much more do the other gatekeeper intermediaries contribute to the malaise? Our claim is that one of the chief factors that contributed to the ethical failure of professional accountants and members of other professions to live up to their responsibilities was that they forgot the purpose and role they were to play in the system and became motivated by purely monetary concerns. An exclusive monetary concern cannot function as an ultimate end and using monetary concerns as such an end will lead accounting firms to abandon their responsibilities and their proper goals while falling into the trap of accumulating wealth for its own sake. The firms forget what their professional aims are to be about.

\footnotetext{
${ }^{26}$ One of the richest sources of the Byzantine structures created by Enron is found in First Interim Report of Neal Baston, Court-Appointed Examiner, United States Bankruptcy Court, Southern District of New York, In re: Enron Corp., et al., Debtors. 21, September 2002. These ought to indicate numerous areas and transactions, which should have served as red flags for an auditor who was sufficiently "skeptical".
} 


\section{Accumulation as a factor in accounting firms}

In the recent business scandals, not only did the officials of companies such as Enron, Tyco, WorldCom and Global Crossing (to mention only a few) get swept up in what I have called "accumulation fever." 27 Accounting firms also got caught. It was no accident that since the majority of revenues and hence profits for accounting firms in the 1990s began to come from consulting rather than auditing accounting firms lost their focus on the importance of responsible auditing.

This switch from auditing to consulting as the main source of revenue was more or less true of all the big five accounting firms, and it seems clear that the main motive for pursuing consulting was to accumulate more sources of revenue without consideration of how this would affect their responsibilities to the public and the system.

As Lynn E. Turner of the SEC said:

Where as recently as the early 1980s, the accounting firm's principal source of revenues were from the performance of audits, a survey of 563 of the Fortune 1000 companies showed that for every $\$ 1$ of revenues generated for the performance of the review and audits of the quarterly and annual financial statements in 2000, \$2.69 in revenues were generated by providing other services. Those other services accounted for 73 per cent of total fees billed by the accounting firms to the companies surveyed. ${ }^{28}$

As the large accounting firms grew, they began to expand but failed to consider the purpose of the expansion. Was it to do consulting? Consulting is a noble profession, but is that why the accounting firms engaged in it, or was it simply to bring in more profits? To accumulate more? To make more profits?

There was a rush for profits and growth with little reflection on how this profitable consulting impacted on the primary function of the auditing firm. There was little speculation about how reliance on consulting fees might impact the independence needed for objective auditing. What occurred was that the new profit-making enterprises took the focus off the auditing and what's more caused a new view about an auditor's responsibilities. While this is true of all the big five firms to an extent, we have used the behaviour of Arthur Andersen as an example of what happened industry wide.

A venerable firm like Andersen at one time prided itself in its role as auditor since it fulfilled an important public function. As an auditor, Arthur Andersen had a clear mission to attest that the financial statements it was auditing reflected what was really going on in the company. However, since more money was to be made in consulting, the responsibilities that the firm should have met as auditor were compromised for the sake of ever increasing fees. Accumulation caused Andersen to lose sight of its purpose and hence lose its moral bearings.

\footnotetext{
${ }^{27}$ See a forthcoming article in Business and Professional Ethics Journal, "The Corruption of Financial Markets: Systemic Inevitability or Aberration?"'

${ }^{28}$ Lynn E. Turner, 2001, "Independence: A Covenant for the Ages", at International Organization of Securities Commissions, Stockholm Sweden, 28 June 2001. www.sec.gov/news/speech/spch504.htm.
} 
While it seems clear that accumulation fever and the consequent abandonment of responsibility lead to ethical dereliction of duty, it is rare that things are done without some attempt to justify (rationalize?) the activities. The companies suffering accumulation fever appeal to the old canard that the main purpose of business is to maximize profits or shareholder wealth, or some such notion. In short, the only end is the end of making more profit. But if that is the only end, where are the limits on what can and cannot be justified in the making of profit? There would be only one limitation and that would be the law. Only what is illegal is considered unethical. A mere accumulator will only be deterred or limited by the law.

Such a rationalization, discouragingly enough, leads us back in time to an article that appeared in the Harvard Business Review a half century ago by Albert Carr, called "Is Business Bluffing Ethical?" The article claimed that the only responsibility a business had was to pursue profit and its only constraint was to obey the law. One had thought that ethics in business had progressed to a point where business seriously considered ethical matters, and tried to live within the spirit of the law, rather than just the letter of the law, that is, did the right thing and not just skirted the legal edge went beyond mere legal compliance. However, an accumulation spirit seems to have infected business and with accumulation as the primary goal, the sole limit on activity is the law, and energy is spent trying to find loopholes to allow for the accumulation of even more money - a typical compliance mentality.

\section{Conclusion}

To sum up, becoming a mere accumulator means you forget your primary responsibility that is dictated by your purpose. When the pursuit of money and commissions or fees is the major driver of an accounting firm, that firm forgets its responsibilities. When a company strives only to maximize profit and forgets its mission of producing goods and services, it leaves aside ethics and values. When accumulation of wealth is the only driver the lack of responsibility inevitably follows.

To the extent that the accumulator disposition infiltrates or pervades a person or industry, the person or industry gets corrupted, because to that extent it loses its purpose. The ethical course is to keep one's goal of serving others in mind: Executives to fulfil their fiduciary responsibilities to shareholders and other stakeholders by profitably making a useful product; auditors to fulfil their responsibilities to the general public to make sure financial statements "fairly" present a picture of the financial situation of a company for those with a need to use them; and others to fulfil whatever responsibilities they have in the varied world of financial services. Such a pursuit of honourable goals makes life eminently worth living.

\section{References}

AICPA Statements on Auditing Standards, “The Auditor's Responsibility To Detect And Report Errors And Irregularities", No. 55 SAS 53.

Aquinas, T. (1947) Summa Theologica I-II, Q. 21 art. 2, ad. 2 (The Basic Writings of St. Thomas Aquinas, translated and edited by Anton Pegis), New York: Random House. 
Baker, C.R. and Hayes, R.S. (1996) 'Regulating the Public Accounting Profession: An International Perspective, from', http://les.man.ac.uk/cpa96/papers.htm/baker2.htm, p. 9.

Bogle, J.C. (2000) 'Public Accounting: Profession or Business?', a speech delivered at New York University NYU, 16 October 2000.

Briloff, A.J. (1999) "The 'Is' and the 'Ought'”, Accounting Today, 6-26 September, p. 6.

Burger, J.W. (1984) United States v Arthur Young and Co. et al., 104 S.Cr, 465 U.S. 805.

Duska, R. (2004) 'The corruption of financial markets: Systemic inevitability or aberration?', Business and Professional Ethics Journal 23(Spring/Summer), Nos. 1 and 2: 223-244.

Reahi-Belkhauli, A. (1992) Morality in Accounting, New York: Quorum Press.

Shillinglaw, G. (1993) 'Accounting', The New Encyclopedia, Britannica: Macropaedia, Vol. 13, 15th edn, Chicago.

Turner, L.E. (2001) 'Independence: A Covenant for the Ages', at International Organization of Securities Commissions, Stockholm Sweden, 28 June 2001,www.sec.gov/news/speech/spch504.htm.

United States Bankruptcy Court (Southern District of New York) (2002) First Interim Report of Neal Baston, Court-Appointed Examiner, in re: Enron Corp. et al. debtors, 21 September 2002.

\begin{abstract}
About the Author
Ronald F. Duska, Ph.D., holds the Charles Lamont Post Chair of Ethics and the Professions at The American College and is the director of the Center for Ethics in Financial Services at the College. His most recent books The Ethics of Accounting and Ethics for the Financial Services Professional were published in 2003. He has authored numerous articles on philosophy and business ethics and is a lecturer and consultant on business ethics and offers continuing education seminars and workshops on business ethics in the financial services industry. Professor Duska earned his Ph.D. in philosophy from Northwestern University, where his primary research was in the area of ethical theory.
\end{abstract}

